\title{
FOLLICULAR GROWTH: THE BASIC EVENT IN THE MOUSE AND HUMAN OVARY
}

\author{
HANNAH PETERS, ANNE GRETE BYSKOV, \\ RUTH HIMELSTEIN-BRAW AND MOGENS FABER \\ The Finsen Laboratory, The Finsen Institute, Copenhagen, Denmark
}

\begin{abstract}
Summary. Follicular growth is described as a continuum. It goes on at all times, at all ages, uninterrupted by pregnancy or other periods of non-ovulation. A distinction is made between the continuum at the beginning of follicular growth and events concerning the cyclicity at the end of follicular growth, i.e. ovulation. Follicles grow sequentially. Also large follicles continue to grow until they become atretic or ovulate. No evidence for a pool of large follicles held in reserve could be found. Examination of the effect of PMSG on the growth of large follicles showed that this hormone prevented the degeneration of large follicles, thus allowing more follicles to grow further.

As in the mouse, follicular growth occurs during human infancy and is the normal event during childhood. Ovaries without signs of follicular growth are uncommon in the child and are apparently connected with certain systemic diseases.
\end{abstract}

\section{INTRODUGTION}

The functioning of the ovary depends on the interplay of several mechanisms which lie partly outside the organ and partly within the ovary itself. Their co-ordination leads to the growth of many follicles and the eventual ovulation of a few. Ovulation in many mammals is spontaneous and apparently regular, while in others genital stimulation is necessary to initiate the events leading to ovulation. The regular and cyclic event of spontaneous ovulation in rodents stimulated the discovery of the reciprocal relationship between the ovary and the pituitary (Moore \& Price, 1932) and the central nervous system (Hohlweg \& Junkman, 1932; for review see Barraclough, 1973).

The emphasis on the role of the feedback mechanisms between the gonad, the central nervous system and the pituitary in rodents overshadowed for some years one of the basic events within the ovary itself, namely follicular growth. In the present paper, the first question that is raised is whether follicular growth and in particular the onset of growth is a cyclic event or should be considered a continuum. We then examine whether those follicles that enter the growth phase can proceed only to a certain stage and then stop, thus creating a reserve 
of large follicles (Greenwald, 1973) ready to complete their growth only after a certain signal is received from the pituitary. These questions are examined taking the mouse ovary as a model, and then follicular growth in the infant and juvenile human ovary is discussed and compared with that in the mouse.

\section{FOLLICULAR GROWTH: A CONTINUUM OR A GYGLIG EVENT?}

In order to clarify whether the growth of a follicle is continuous or not, the ovary of the mouse in three different states is considered: (i) during infancy, when ovulation is still to commence; (ii) during maturity, when the cycle has become established; and (iii) during pregnancy, when ovulation is held in abeyance until the birth of the young.

\section{During infancy}

Most of the eggs in an ovary rest within the small, non-growing follicles. These represent the pool from which developing and maturing follicles emerge at one time or another during the animal's life. Follicular growth begins when the oocyte starts to enlarge and granulosa cells multiply.

The first follicles begin to grow during the first week of life. The distribution of the growing follicles is characteristic; they are found in the inner part of the cortex, while the non-growing small follicles lie in the outer cortex (Peters, 1969). This growth pattern is not only found in the mouse but is the rule in the ovary of young mammals (Mossman \& Duke, 1973). This might be a consequence of the fact that, in the neonatal ovary, the first small follicles are formed by the first oocytes to come in contact with the centrally located rete ovarii cells (Byskov \& Lintern-Moore, 1973). Subsequently it is also these follicles that first begin to develop (Byskov, 1975). In 2-week-old mice, some of the growing follicles are larger than those a week before, and additional follicles have left the pool and started to grow. When the animal is 3 weeks old many healthy and degenerating large follicles populate the ovary, together with mediumsized ones and some just starting growth.

At the time of the first ovulation, the ovary contains the ovulating follicles, follicles that started to grow many days before, and those that are in the earliest phases of growth.

Pedersen (1972) used autoradiographic techniques to determine the number of follicles leaving the pool of non-growing follicles in mice at different ages. The number that begin to grow is highest at the end of the first week of life (41), decreases to half by the time the animal is 3 weeks old (21) and remains at about this level in mature, non-pregnant animals (twenty at 1 month, nineteen at 3 months, ten at 9 months, ten at 12 months and three at 16 months). Follicular growth started at all ages in infancy during the juvenile period. Thus it is evident that it is not a single crop of follicles that starts growth and achieves ovulation when the animal becomes mature, but rather that there is a continuous initiation of follicular development during infancy.

\section{During maturity}

As there is a continuous initiation of follicular growth during the infant and 
juvenile period, the question arises whether a cyclic fluctuation becomes established after the animal has become mature and has started to ovulate. Kinetic studies of follicles showed that during each day of the cycle follicles begin to grow and that those that start growth grow continuously until they become atretic or ovulate (Pedersen, 1970).

\section{During pregnancy}

It is of considerable interest to find out whether follicular growth ceases during pregnancy when ovulation is held in abeyance. The pattern of follicular growth throughout pregnancy in the mouse was investigated by autoradiographic techniques (Pedersen \& Peters, 1971). New follicles started to grow on each day. Furthermore, follicles in all stages of development (except preovulatory follicles) were observed on the different days of pregnancy.

In the hamster growing and large follicles are also found at all stages of gestation; Greenwald et al. (1967) reported that during the first 8 days of pregnancy the hamster ovary resembled that of the cyclic animal. The numbers of antral follicles were comparable to those found during the oestrous cycle until the 12th day of pregnancy, when their number increased sharply. A continuous growth of follicles of all sizes is reported in the rat during pregnancy (Schwartz \& Talley, 1968). Govan $(1968,1970)$ describes the presence of pre-antral follicles throughout the different stages of pregnancy in women and small antral follicles occurring early and large antral follicles appearing later in gestation. We therefore conclude that follicular growth occurs continuously during pregnancy.

Follicular growth cannot therefore be considered a cyclic event. From the pool of non-growing follicles, follicles emerge to start growth regardless of the age of the animal and of its reproductive stage, and the final fate of the follicle. There is therefore a sharp distinction between the continuum of the follicular growth and the cyclic event of ovulation.

The beginning of follicular growth is apparently regulated by intraovarian mechanisms. The number of follicles that start to develop is dependent on the size of the pool of small follicles. The larger the pool, i.e. the larger the number of small follicles still in the ovary, the more follicles begin development per unit time (Krarup et al., 1969). Furthermore, it has been suggested that degenerating follicles contain a substance which reduces the initiation of follicular growth (Peters et al., 1973a). The gonadotrophins which play a central role in the very last stages of follicular development do not seem to influence the earliest stages. The number of follicles beginning to grow is not altered by blocking the secretion of the endogenous gonadotrophins (Eshkol et al., 1970) or by injection of exogenous gonadotrophins (Peters et al., 1973b).

\section{DO LARGE FOLLIGLES FORM A POOL OF RESERVE FOLLICLES?}

Greenwald (1973) proposed that follicles grow to a certain stage, then stop developing to form a pool of reserve follicles from which they can be recruited by gonadotrophin stimulation. This hypothesis can be tested in several ways. The presence of a pool of non-growing, resting, large follicles should be de- 
tectable in follicle kinetic studies, using a radioactive DNA precursor as a label. Resting large follicles would be characterized by being unlabelled in autoradiograms prepared shortly after label injection. Furthermore, if at the time of label injection the granulosa cells of a large follicle still synthesized DNA and it subsequently became a reserve, i.e. resting, follicle delayed autoradiograms prepared some days or cycles after label injection would show large follicles still with heavily labelled granulosa cells. Both of these experiments have been done repeatedly (Peters \& Levy 1966; Pedersen, 1972; Byskov, 1974), but no evidence for a pool of reserve follicles could be found in mice. There were no large healthy follicles without labelled granulosa cells in autoradiograms prepared 1 hour after injection of the label, and large follicles with only heavily labelled granulosa cells have not been observed in delayed autoradiograms. Cell dynamic studies therefore show that in the mouse follicles grow sequentially. A pool of reserve follicles could not be confirmed.

THE ROLE OF GONADOTROPHINS IN FOLLICULAR DEVELOPMENT

The dependence of medium-sized and large follicles on gonadotrophins for normal growth is well known (for review see Greenwald, 1974b). After hypophysectomy the maturation of follicles is markedly curtailed (Smith, 1930; Paesi, 1949). However, it has not yet been clarified at what stage of growth of the follicle the dependence on pituitary hormones becomes established, and the effects of endogenous or exogenous gonadotrophin on the events of follicular development are not entirely clear. It has hitherto been thought that FSH stimulates reserve follicles to grow (Greenwald, 1973) or is responsible for the recruitment of the next set of follicles for ovulation (Schwartz, 1969; Welschen, 1973; Greenwald, 1974a). However, as a pool of resting large follicles does not seem to exist in the ovary, another mechanism of FSH action must be postulated. In experiments in which superovulation is induced the injection of PMSG plus an ovulating hormone results in the release of many more than the usual number of eggs. How can this be explained if a pool of resting large follicles is not available to be stimulated by the injection of gonadotrophin? Gould we assume that the action of FSH is not to stimulate resting large follicles to resume growth but rather to protect some of the large developing follicles from atresia? This has recently been tested by analysing the effect of superovulation-inducing treatment on the large follicles instead of counting the number of eggs in the oviduct. Three 21-day-old mice were injected subcutaneously with 5 i.u. PMSG (Antex, Leo) and killed $24 \mathrm{hr}$ later. Untreated litter mates served as controls. The sections of the ovaries looked strikingly different in the two groups. The granulosa cells of the large follicles in the mice injected with PMSG looked healthy, while in the control animals many large follicles had pyknotic cells. Though the number of animals was small (three in each group) a quantitative comparison was made.

The number of medium-sized and large follicles was counted differentially (Mandl \& Zuckerman, 1951) and the number of atretic follicles was determined. A follicle was judged to be atretic if at least one pyknotic granulosa cell was seen in the largest cross-section of the follicle. The total number of large 
follicles in the two groups did not differ but the proportions of those follicles that were atretic did vary (Table 1). It is inferred that PMSG did not increase the number of large follicles that developed, but changed the balance between healthy and atretic follicles by preventing or delaying atresia in some of them.

Table 1. The number of healthy and atretic large follicles in the ovaries of 22-day-old mice injected with 5 i.u. PMSG $24 \mathrm{hr}$ before death and of their littermate controls

\begin{tabular}{cccc}
\hline $\begin{array}{c}\text { Treatment } \\
\text { and animal }\end{array}$ & $\begin{array}{c}\text { Total no. of } \\
\text { large follicles }\end{array}$ & $\begin{array}{c}\text { No. of } \\
\text { atretic follicles }\end{array}$ & $\begin{array}{c}\text { Atretic follicles/ } \\
\text { total no. of large } \\
\text { follicles } \times 100\end{array}$ \\
\hline PMSG & & & \\
1 & $139 \cdot 3$ & $53 \cdot 6$ & $38 \cdot 5$ \\
2 & $132 \cdot 1$ & 46.4 & $35 \cdot 1$ \\
3 & 85.7 & 21.4 & $25 \cdot 0$ \\
Control & & & $(32.9 \pm 4 \cdot 1)^{*}$ \\
4 & 171.4 & $135 \cdot 7$ & $79 \cdot 2$ \\
5 & 103.6 & $78 \cdot 6$ & $75 \cdot 9$ \\
6 & 53.4 & 39.3 & $73 \cdot 5$ \\
& & & $(76 \cdot 2 \pm 1 \cdot 6)^{*}$ \\
\hline
\end{tabular}

* Means \pm S.E.M. which are significantly different at $P<0.001$.

\section{Conclusion}

Follicular growth starts when a follicle emerges from the pool of nongrowing small follicles. The initiation of growth is continuous during infancy and maturity, regardless of whether the animal ovulates. It is independent of gonadotrophins and apparently influenced by the mass of all small follicles and by factors produced by atretic follicles. The continued growth of mediumsized and large follicles is dependent on gonadotrophic stimulation. A change in the levels of gonadotrophins affects the number of follicles that degenerate. An accumulation of large follicles, held in reserve, unused but available, cannot be verified. The growth of the follicle is sequential until the follicle degenerates or, if enough gonadotrophin is available to support the completion of its growth, it releases the egg.

\section{FOLLICULAR GROWTH IN GHILDHOOD}

The ovarian morphology of children has been described in several publications (Sauramo, 1954; Watzka, 1957; Valdes-Dapena, 1967). All observers noted the presence of large fluid-containing follicles in many ovaries at various ages. However, there have been few systematic investigations which trace the development of the ovary from birth to maturity. For the past 8 years ovaries throughout childhood have been collected at our laboratory and a collection of about 1300 specimens at different ages is now available. The evaluation of ovaries obtained from 'normal' children, i.e. those who had died accidentally or after an acute disease, showed that follicular growth occurred at all ages 
(Lintern-Moore et al., 1974). An analysis of about half of the available collection revealed that follicular growth during childhood is the rule even in chronically ill children. In most ovaries, medium-sized, pre-antral follicles were found (the 'sekundär Follikel' of Watzka, 1957). This finding is significant as these stages, usually overlooked, represent the earliest stages of follicular development. In addition, large follicles with various amounts of fluid were present. Atretic follicles and 'scars', which represent the last recognizable rests of large atretic follicles, were characteristic.

Evaluation of the ovaries of 1- to 3-year-old children showed that three states of ovarian development can be distinguished (Table 2). (1) The actively growing ovary is one in which many medium-sized follicles, several fluidfilled large follicles as well as degenerating and scars of large follicles are seen. (2) The ovary showing early growth contains medium-sized follicles but none or only one small fluid-filled follicle. (3) The quiescent ovary is a small ovary in which the total ovarian mass is often reduced; very little follicular growth is seen, and only an occasional medium-sized follicle might be found. During the analysis it was noted that two of the three quiescent ovaries came from children with Down's syndrome. A delay or inhibition of follicular growth in children with Down's syndrome was confirmed by further study (Table 2).

Table 2. Ovarian development in childhood

\begin{tabular}{lcccc}
\hline Age & $\begin{array}{c}\text { No. of } \\
\text { cases }\end{array}$ & $\begin{array}{c}\text { Ovaries } \\
\text { actively } \\
\text { growing }\end{array}$ & $\begin{array}{c}\text { Ovaries } \\
\text { showing } \\
\text { early } \\
\text { growth }\end{array}$ & $\begin{array}{c}\text { Quiescent } \\
\text { ovaries }\end{array}$ \\
\hline $\begin{array}{l}1 \text { year } \\
3 \text { years }\end{array}$ & 15 & 11 & 3 & 1 \\
Total & 16 & 11 & 3 & 2 \\
\hline 5 days to & 31 & $22(71 \%)$ & $6(19 \%)$ & $3(10 \%)$ \\
7 years & $13 *$ & $3(23 \%)$ & - & $10(77 \%)$ \\
\hline
\end{tabular}

* Children with Down's syndrome.

We therefore affirm that follicular growth is also a basic event in the human ovary. It starts in infancy and is found at all ages during childhood. In those cases in which it is absent a systemic disease must be suspected.

\section{ACKNOWLEDGMENTS}

The authors would like to thank Else Chilton, Inga Larsen and Annelise Mohr for excellent technical assistance. We also wish to thank the pathologists who kindly supplied ovaries used in this study: Dr A. D. Bain, Royal Hospital for Sick Children, Edinburgh; Dr J. M. Bouton, Alderhey Children's Hospital, Liverpool; Dr A. E. Claireaux, Hospital for Sick Children, London; Dr G. Kohn and Dr J. Chatten, Children's Hospital, Philadelphia; and Dr H. B. Marsden, Royal Manchester Children's Hospital, Manchester. Part of this 
study was carried out in partial fulfilment of EURATOM Contract 120-73-1 BIODK.

\section{REFERENCES}

Barraclough, G.A. (1973) Sex steroid regulation of reproductive neuroendocrine processes. In Handbook of Physiology, Section 7: Vol. II, part 1, pp. 29-56. Ed. R. O. Greep. American Physiological Society, Washington D.C.

Byskov, A.G. (1974) Cell kinetic studies of follicular atresia in the mouse ovary. 7. Reprod. Fert. 37, 277285.

Byskov, A.G. (1975) The role of the rete ovarii in meoisis and follicle formation in the cat, mink and ferret. 7. Reprod. Fert. 45, 201-209.

Byskov, A.G. \& Lintern-Moore, S. (1973) Follicle formation in the immature mouse ovary: the role of the rete ovarii. 7. Anat. 116, 207-217.

Eshkol, A., Lunenfeld, B. \& Peters, H. (1970) Ovarian development in infant mice. Dependence on gonadotropic hormones. In Gonadotrophins and Ovarian Development, pp. 249-258. Eds. W. R. Butt, A. C. Crooke \& M. Ryle. E. and S. Livingstone, Edinburgh and London.

Govan, A.D.T. (1968) The human ovary in early pregnancy. J. Endocr. 40, 421-428.

Govan, A.D.T. (1970) Ovarian follicular activity in late pregnancy. J. Endocr. 48, 235-241.

Greenwald, G.S. (1973) Distinction between developing and reserve follicles in the cycling hamster. Annls Biol. anim. Biochim. Biophys. 13, 199-210.

Greenwald, G.S. (1974a) Quantitative aspects of follicular development in the untreated and PMStreated cyclic hamster. Anat. Rec. 178, 139-144.

Greenwald, G.S. (1974b) Role of FSH and LH in follicular development and ovulation. In Handbook of Physiology, Section 7, Endocrinology. Ed. E. Knobil. American Physiological Society, Washington, D.C.

Greenwald, G.S., Keever, J.E. \& Grady, K.L. (1967) Ovarian morphology and pituitary FSH and LH concentration in the pregnant and lactating hamster. Endocrinology 80, 851-856.

Hohlweg, W. \& Junkman, K. (1932) Die hormonal-nervöse Regulierung der Funktion des Hypophysenvorderlappens. Klin. Wschr. 15, 321-323.

Krarup, T., Pedersen, T. \& Faber, M. (1969) Regulation of oocyte growth in the mouse ovary. Nature, Lond. 224, 187-188.

Lintern-Moore, S., Peters, H., Moore, G.P.M. \& FAber, M. (1974) Follicular development in the infant human ovary. 7. Reprod. Fert. 39, 53-64.

MANDl, A. \& Zuckerman, S. (1951) The relation of age to numbers of oocytes. 7. Endocr. 7, $190-193$.

Moore, G.R. \& Price, D. (1932) Gonad hormone functions, and the reciprocal influence between gonads and hypophysis with its bearing on the problem of sex hormone antagonism. Am. F. Anat. 50, 13-61.

Mossman, H.W. \& Duke, K.L. (1973) Comparative Morphology of the Mammalian Ovary. University of Wisconsin Press.

PaEsi, F.J.A. (1949) The influence of hypophysectomy and of subsequent treatment with chronic gonadotrophin on follicles of different sizes in the ovary of the rat. Acta endocr., Copenh. 3, 89-104.

Pedersen, T. (1970) Follicle kinetics in the ovary of the cyclic mouse. Acta endocr., Copenh. 64, $304-323$.

Pedersen, T. (1972) Follicle growth in the mouse ovary. In Oogenesis, pp. 361-376. Eds J. D. Biggers \& A.W. Schuetz. University Park Press, Baltimore.

Pedersen, T. \& Peters, H. (1971) Follicle growth and cell dynamics in the mouse ovary during pregnancy. Fert. Steril. 22, 42-52.

Peters, H. (1969) The development of the mouse ovary from birth to maturity. Acta endocr., Copenh. 62, 98-116.

Peters, H. \& Levy, E. (1966) Cell dynamics of the ovarian cycle. F. Reprod. Fert. 11, 227-236.

Peters, H., Byskov, A.G. \& Faber, M. (1973a) Intraovarian regulation of follicle growth in the immature mouse. In The Development and Maturation of the Ovary and its Functions, pp. 20-23. Excerpta Medica, Int. Congr. Ser. No. 267.

Peters, H., Byskov, A.G., Lintern-Moore, S., Faber, M. \& Andersen, M. (1973b) The effect of gonadotrophin on follicle growth initiation in the neonatal mouse ovary. 7. Reprod. Fert. 35, 139-141.

Sauramo, H. (1954) Histology and function of the ovary from the embryonic period to the fertile age. Acta obstet. gynec. scand. 33, Suppl. 2, 1-25.

Schwartz, N.B. (1969) A model for the regulation of ovulation in the rat. Recent Progr. Horm. Res. 25, $1-54$.

Schwartz, N.B. \& TAlley, W.L. (1968) Daily measurement of pituitary LH content during pregnancy in the rat: do cyclic changes persist? $\mathcal{F}$. Reprod. Fert. 15, 39-45. 
Smith, P.E. (1930) Hypophysectomy and a replacement therapy in the rat. Am. F. Anat. 45, 205-273. Valdes-Dapena, M.A. (1967) The normal ovary of childhood. Ann. N.Y. Acad. Sci. 142, 597-613.

Watzka, M. (1957) Weibliche Genitalorgane. Das Ovarium. In Handbuch mikrosk. Anat. Menschen. Vol. 7. Eds W. V. Möllendorf \& W. Bargmann. Springer-Verlag, Berlin.

Welschen, R. (1973) Amounts of gonadotrophins required for normal follicular growth in hypophysectomized adult rats. Acta endocr., Copenh. 72, 137-155. 